\title{
Entrepreneurial Skill Acquisition and Youth's Self-Employment in Malaysia: How Far?
}

\author{
*1 Isidore Ekpe \\ ${ }^{2}$ Razli Che Razak \\ ${ }^{3}$ Mohammad Ismail \\ ${ }^{4}$ Zulhamri Abdullah \\ 1, 2, 3 Faculty of Entrepreneurship and Business, Universiti Malaysia Kelantan, \\ City Campus, Pengkalan Chepa, 16100 Kota Bharu, Kelantan, Malaysia \\ ${ }^{4}$ Centre of Entrepreneurial Development and Graduate Marketability, Universiti Putra Malaysia, \\ 43400 UPM Serdang, Selangor, Malaysia \\ Email: ${ }^{1}$ isidore.e@umk.edu.my, ${ }^{2}$ razlicr@umk.edu.my, ${ }^{3}$ mohammad.@umk.edu.my, zulhamri@upm.edu.my \\ *1=Dr. Isidore Ekpe (Senior Lecturer, Corresponding Author), ${ }^{2}=$ Professor, ${ }^{3}=$ Assoc. Prof., ${ }^{4}=$ Assoc. Prof.
}

\section{Doi:10.5901/mjss.2015.v6n4p150}

\begin{abstract}
The objective of this study was to examine the moderating effect of self-motivation on the relationship between entrepreneurial skill acquisition and self-employment practice among graduates from Malaysian public universities. It is a known fact that youth enterprises could generate employment opportunites and lead to economic growth of a country; however, researches have reported that most of entrepreneurship graduates from Malaysian universities do not go into entrepreneurship practice five years after graduation. To test this relationship, a conceptual model was developed based on Ajzen (1991) theory. The study recommended that Malaysian government and community leaders should draft appropriate strategies (for example counseling in school), that will encourage and engender greater participation of the youths in self-employment practice.
\end{abstract}

Keywords: Skill acquisition, self-motivation, self-employment, Malaysian universities graduates

\section{Introduction}

Studies have shown that enterprises contribute positively to an economy locally and globally, especially to GDP and employment at the grassroots (Mahmood \& Hanafi, 2013; Subramaniam, 2010). In Malaysia, for example, there were 2.2 million entrepreneurs in 2008, and micro-enterprises accounted for $79.4 \%$ of the total SMEs and almost $78.7 \%$ of business establishments; and Micro and SMEs contributed about 64\% of total employment and generated RM 159,411 million of value added in 2003 (Nawai \& Shariff, 2011).

Entrepreneurship development, therefore, is considered a vital link to an overall economic growth of a nation through its positive impact on economic development especially at the grassroots (Barringer \& Ireland, 2012; Weihrich et al. 2008). Entrepreneurships help to create wealth and reduce unemployment, produce creativity and innovation, and increase the total production of a country (Shane, 2003). Arguably, the technological advancement or transformation in any country mostly can be made possible through innovative sciences, ideas and utilizing uncommon opportunities; and entrepreneurship is the best way to achieve this. People become gainfully employed through vocational training and skill acquisition (Ebong \& Asodike, 2011; Ikegwu, 2014; Nwanaka \& Amaehule, 2011).

Globally, entrepreneurship skill acquisition programs introduced into educational institutions were meant to provide the level of education or knowledge needed to exploit entrepreneurial opportunity which could help the economic development of such countries (Emaikwu, 2011; Shane, 2003), and studies have shown that skill acquisition is the most critical factor in the utilization of entrepreneurship opportunity for self-employment (Ekpe et al., 2012). In line with this, the Malaysian government has put in place several entrepreneurship development programs, including the introduction of entrepreneurship courses and establishment of entrepreneurship departments in various universities in the country in order to train aspiring entrepreneurs. The aim of such programs was to impact skills, attitudes, aspirations and competencies mostly in the youths, and provides micro-credit, to enable them practice entrepreneurship or create selfemployment as well as help generate employment for others (Abdullah et al., 2009; Samian \& Buntat, 2012). 
Each year, many students graduate from Malaysian public universities. For example, from the Universiti Malaysia Kelantan 2013 Convocation, a total of 538 Bachelor Degree students graduated in 2013 (Konvokesyen Ke-3, 2013, pp.18, 73-86). This number is a result of high school enrolment and attendance in the country. With such level of graduates, their contribution to the national economy is quite high in term skill, knowledge and competencies; and to their families in terms of financial supports. In this way, they are highly empowered to contribute positively to national economic, political and social policies as well as participate in community decisions affecting them. However, despite the numerous government entrepreneurship development programs and the importance of entrepreneurial skill acquisition to self-employment practice, it is observed, and previous studies have also reported, that most of entrepreneurship graduates from Malaysian universities do not go into entrepreneurship practice five years after graduation by identifying and exploiting entrepreneurial opportunities (Abdullah et al., 2009; Samian \& Buntat, 2012). The question is: what could be the hindering factors?

Previous studies were available on the relationship between skill acquisition and entrepreneurial opportunity or self-employment (Abdullah et al., 2009; Ikegwu, 2014; Nwanaka \& Amaehule, 2011; Ojo, 2009; Onuoha et al. 2013; Samian \& Buntat, 2012) but there was scarcity of research that empirically measured entrepreneurial skill acquisition and self-employment practice, with psychological factor (self-motivation) as moderator especially in developing country like Malaysia. Entrepreneurial skill acquisition could not lead to self-employment practice without considering entrepreneur's characteristics or attitudes such as self-motivation.

Motivation is a general term applying to the entire class of drives, desires, needs, wishes and similar forces (Weihrich et al., 2008). As such, an individual can be motivated by personal drive or desire to achieve success. Attitudinal studies (e.g Ajzen, 1991) have also shown that a person's attitude correlates with his/her intention or commitment. Previous literature (Amadi, 2012; Ojo, 2009; Shane, 2003) have agreed that entrepreneurial skill acquisition is positively related to opportunity for self-employment. However, self-motivation can aid or hamper this relationship because a graduate who had received entrepreneurial skill acquisition may not venture into entrepreneurship practice if he/she is risk-averse characterized person, has a negative attitude to hard work, and misuses the acquired knowledge, talent or skill. This is in line with human development and welfare issues which places the 'individual' at the centre of employees' motivation. It is also observed that Malaysia does not have entrepreneurship programs at the Primary and Secondary School levels like other developing countries such as Nigeria; as such there is no enough motivation for youth entrepreneurs. Hence, the inclusion of psychological factor (self-motivation) as moderator, and their empirical measurements in this study is a novel contribution which helps to strengthen the existing theories on entrepreneurship.

\section{Literature Review}

\subsection{Entrepreneurial Skill Acquisition}

Entrepreneurial skill acquisition is a process whereby a person acquires or learns a particular skill or type of behavior needed for business through training or education (Amadi, 2012; Chukwunenye \& Igboke, 2011; Ibru, 2009; IFC, 2007) in order to identify and exploit entrepreneurial opportunity for self-employment (Samian \& Buntat, 2012; Stohmeyer, 2007). It also helps entrepreneurs to acquire self-confidence, self-esteem and participate in decision-making at household and community levels (Cheston \& Kuhn, 2002; Rufai et al., 2013). Skill training and tertiary education could lead to business opportunities and impact on entrepreneurship (Emaikwu, 2011; Gatewood et al., 2004). Exploitation of entrepreneurial opportunity also depends on the entrepreneur's level of education, skills or knowledge acquired through training, work experience and social network (Shane, 2003; Shastri \& Sinha (2010). Training and/or education produce prior experience which leads to preparedness for entrepreneurial activity (Shane, 2003).

The awareness of the need for entrepreneurial skill training and supports in order to stimulate entrepreneurial activity and reduce business failure have been increased among stakeholders in the industry, business and government of many countries because entrepreneurs could be born or made (Abdullah et al., 2009). It is also a vital source of developing human capital (Brana, 2008; Ikegwu, 2014). Though Rufai et al. (2013) and Dasmani (2011) found that entrepreneurship graduates could not get employment because they possessed low skills and low self-confidence required by industries since there was no industrial exposures while in school, however; numerous studies asserted that skill training and tertiary education could lead to entrepreneurial activity or self-employment (Amadi, 2012; Salman, 2009; Stohmeyer, 2007). Skill acquisition training was found to have positive effect on entrepreneurial activity in Nigeria (Ebong et al., 2011; Ekpe \& Mat, 2012; Ibru, 2009; Ikegwu, 2014). Skill acquisition training was found to have positive effect on entrepreneurial activity in France (Brana, 2008). Skill acquisition training had positive impact on entrepreneurial opportunity in Germany (Stohmeyer, 2007). Skill acquisition training was also found to have positive effect on 
entrepreneurial activity in Malaysia (Samian \& Buntat, 2012). We therefore hypothesized that: graduates.

H1: Entrepreneurial skill acquisition is positively related to self-employment practice among the university

\subsection{Self-Motivation}

Weihrich et al. (2008) refers to motivation as a general term applying to the entire class of drives, desires, needs, wishes and similar forces. Therefore, one can be motivated by personal/self drive or desire to achieve success. Attitude towards behaviour means the degree to which an individual has a favourable or unfavourable evaluation of the behaviour (Ajzen, 1991). For entrepreneurial intentions to be translated into self-employment, it depends on the entrepreneur's personality and abilities (Majumdar, 2008). Studies, such as Crisp and Turner (2007), found that attitude and behavioural intentions are positively related; and attitude towards behaviour leads to intention which eventually leads to actual behaviour (Ajzen, 1991). It has also been posited by previous literature (Emaikwu, 2011; Onuoha et al. 2013; Salman, 2009; Shane, 2003; Stohmeyer, 2007) that skill training and tertiary education could lead to entrepreneurial activity or self-employment. Other studies also found a positive relationship between skill acquisition and self-employment (Kickul et al., 2007; Ojo, 2009; Samian \& Buntat, 2012). However, self-motivation can aid or hamper these variables' relationship because an entrepreneurship graduate may not venture into self-employment if he/she is not determined to work hard, is risk-averse or misuses the acquired skill (Udida et al., 2012). This is in line with attitudinal studies (e.g Ajzen, 1991) which place the 'individual' at the centre of employees' motivation; hence the introduction of a moderator in this study, in line with Baron and Kenny (1986). We therefore hypothesized that:

H2: Self-motivation moderates the relationship between entrepreneurial skill acquisition and self-employment practice among the university graduates.

\subsection{The Conceptual Model of the Study}

The focus of this study was to examine the relationship between entrepreneurial skill acquisition and self-employment practice, moderated by self-motivation. The study developed a conceptual model which had a link with Schumpeter 1942 Entrepreneurship Theory and Ajzen 1991 Theory of Planned Behaviour. The conceptual model for this study is as shown in Figure 2.1 below.

Figure 1: The Conceptual Model

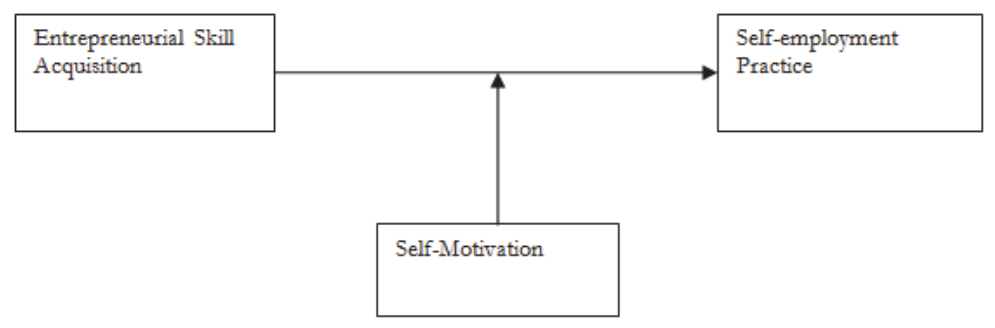

\section{Methodology}

The study employs a cross-sectional survey method to solicit responses from Malaysian University Graduates of Entrepreneurship for the past five years (2009 to 2014); using questionnaires and stratified random sampling. This is because five years is the minimum period for trained entrepreneur to transit to actual practice (Stohmeyer, 2007). Three universities from three zones of Malaysia Peninsular are studied. The method is also used because University' Business and Entrepreneurship Faculties offer similar courses. The study employs descriptive statistics and multiple regressions as data analysis method.

Skill training is measured as skill acquisition, general or business training, in line with previous studies (Kickul et al., 2007). Self-motivation is measured in terms of determination to succeed (Osunloye, 2008). Self-employment is defined in terms of the tendency to engage in new business or business expansion; and measured in line with Shane (2003), Tata and Prasad (2008). All measures are tapped on a 4-point scale. 


\section{Conclusion}

Enterprise development is very crucial to a nation's economic development through employment generation. This necessitated the establishment of various enterprise development programs in many countries, Malaysia inclusive, to develop positive mindset especially among the youth towards self-employment practice after school. This objective is much achieved in poorer countries of the world than in countries, like Malaysia, that provide most jobs to university graduates. However, with an upward rise in population of working class and highly educated or skilled citizens, there is the need for Malaysian government and community leaders to draft appropriate strategies (for example counseling in school and at home), that will encourage and engender greater participation of the youths in self-employment practice.

\section{Acknowledgement}

This is a part of the research sponsored by MYGrant: RACE 2014. Thanks to Research Acculturation and Collaborative Effort (UPM/UMK RACE 2015-2017) under Code: R/RACE/A01.00/01230A/001/2015/000233), Malaysia.

\section{References}

Abdullah, S. H., Osman, M. H. \& Rahim, M. S. H. (2009). The key concept of academic technology entrepreneurship in the current practice. Asia Pacific Journal of Innovation and Entrepreneurship, Korea Business Incubation Association , 2 (1), 77-96.

Ajzen, I. (1991). The Theory of Planned Behavior. The Organizational Behavior and Human Decision Processes , 50, 179-211.

Amadi, B .O.(2012). Perceptions of capacity building among youths involved in vocational skills development. Journal of Social and Development Sciences, 3 (6), 214-222.

Antoncic, B. (2006). Impacts of diversification and corporate entrepreneurship strategy making on growth and profitability: A normative model. Journal of Enterprising Culture, 14 (1), 49-63.

Barringer, B \& Ireland, D (2012). Entrepreneurship- Successful lunching of new venture, $4^{\text {th }}$ edition, USA, Pearson Education.

Baron, R. M. \& Kenny, D. A. (1986). The moderator-mediator variable distinction in social psychology research: Conceptual, strategic, and statistical considerations. Journal of Personality and Social Psychology, 51 (6), 1173-1182.

Brana, S. (2008). Microcredit in France: Does gender matter? 5th Annual Conference-Nice. European Microfinance Network.

Cavana, R. Y., Delahaye, B. L. \& Sekaran, U. (2001). Applied business research: Qualitative and quantitative methods. Singapore: Markono Print Media Limited.

Cheston, S. \& Kuhn, L. (2002). Empowering women through microfinance. A case study of Sinapi Aba Trust, Ghana. USA: Opportunity International.

Chukwunenye, I. O. \& Igboke, B. N. (2011). Training, manpower development and job performance: Perception and relevance among civil servants in Ebonyi State of Nigeria. Journal of Economics and international Finance, 3 (6): 399-406.

Crisp, R. J. \& Turner, R. N. (2007). Essential Social Psychology. London: SAGE Publication.

Dasmani, A. (2011). Challenges facing technical institutions graduates in practical skill acquisition in the upper east region of Ghana Asia-Pacific Journal of Corporative Education, Hamilton, New Zealand, 12 (2), 67-77.

Ebong, J. M. \& Asodike, J. D.(2011). Skill preferences of participants of skill acquisition program in Rivers State, Nigeria. British Journal of Humanities and Social Science, 3 (1), 128-136

Ekpe, I. \& Mat, N.(2012). The moderating effect of social environment on the relationship between entrepreneurial orientations and entrepreneurial intentions of female students at Nigerian universities. International Journal of Management Sciences and Business Research, 1 (4): 1-16.

Ekpe, I., Razak, C. R. \& Mat, N.(2012). Loan access, skill acquisition, bonding and the moderating effect of self-confidence on women entrepreneurs' business performance: A case of Nigeria. International Journal of Business and Management Studies, 4 (1): 7785.

Emaikwu, S. O. (2011). Integrating entrepreneurship skill acquisition in the university curriculum for national development Journal of Research in Education and Society, 2 (3), 40-48

Gatewood, E. J., Brush, C. G., Carter, N. M., Greene, P. G. \& Hart, M. M. (2004). Women entrepreneurs, growth and implications for the classroom. USA: Coleman Foundation whitepaper series for the USA Association for Small Business and Entrepreneurship.

Gay, L. R. \& Diehl, P. L. (1996). Research methods for business and management (International Ed.). Singapore: Prentice Hall International Inc.

Hair, J. F., Black, W. C., Babin, B. J. \& Anderson, R. E. (2010). Multivariate data analysis, a global perspective (7th ed.). New Jersey, USA: Pearson Education Inc.

Hair, J. F., Money, A. H., Samouel, P. \& Page, M. (2007). Research methods for business. England: John Wiley \& Sons Limited.

Ibru, C. (2009). Growing microfinance through new technologies. Federal University of Technology, Akure, Nigeria.

Ikegwu, E. M., Ajiboye, Y. O., Aromolaran, A. D., Ayodeji, A. A. \& Okorafor, U. (2014). Human empowerment through skill acquisition: Issues, impacts and consequences- A nonparametric view. Journal of Poverty, Investment and Development- An open access 
International Journal, 5 (1), 94-101

International Finance Corporation (IFC). (2007). Gender entrepreneurship markets, GEM country brief. Afghanistan: GEM.

Israel, G. D. (1992). Determining sample size. Retrieved July 15, 2014, from http://edis.ifas.ufl.edu/pdffiles/PD/PD00600.pdf

Kennedy, J., Drennan, J., Renfrow, P. \& Watson, B. (2003). Situational factors and entrepreneurship. A paper presented at the 16th Annual Conference (28 September-1 October, 2003). Ballarat, Australia: Small Enterprise Association of Australia and New Zealand.

Kickul, J. R., Page, T. C., Gundry, L. K., \& Sampson, S. D. (2007). Women entrepreneurs preparing for growth: The influence of social capital and training on resource acquisition. Journal of Small Business and Entrepreneurship , 20 (1), 169-181.

Kuzilwa, J. (2005). The role of credit for small business success: A study of the National Entrepreneurship Development Fund in Tanzania. The Journal of Entrepreneurship, 14 (2), 131-161.

Mahmood, R. \& Hanafi, N. (2013). Entrepreneurial orientation and business performance of women-owned small and medium enterprises in Malaysia: Competitive advantage as a mediator. International Journal of Business and Social Science , 4 (1), 8290.

Majumdar, S.(2008). Modelling growth strategy in small entrepreneurial business organizations The Journal of Entrepreneurship, 17 (2), 157-168.

Nawai, N. \& Shariff, M. N. M. (2011). The importance of micro financing to the microenterprises development in Malaysia's experience. Asian Social Science, 7 (12), 226-238.

Nwanaka, C.R \& Amaehule, S. (2011). Skill acquisition: Imperative for business studies educators among secondary schools in Rivers State. Mediterranean Journal of Social Sciences, 2 (7), 37-43

Ojo, O. (2009). Impact of microfinance on entrepreneurial development: The case of Nigeria. Faculty of Administration and Business, University of Bucharest, Romania.

Okpukpara, B. (2009). Microfinance paper wrap-up: Strategies for effective loan delivery to small scale enterprises in rural Nigeria. Journal of Development and Agricultural Economics , 1 (2), 41-48.

Onuoha, F. N; Inyiama, H. C; Eze, F. C \& Achi, I. I. (2013) E-skill information acquisition software:A key to poverty alleviation for selfreliance. West African Journal of Industrial and Academic Research, 6 (1), 65-77.

Osunloye, A. (2008). Family background and student academic performance Retrieved July 23, 2014 from http://socyberty.com/edu/ family-background-and-student academic performance/

Pallant, J. (2007). SPSS survival manual: A step by step guide to data analysis using SPSS for windows (3rd ed.). New York, USA: McGraw-Hill Open University Press.

Rufai, A., Abdulkadir, M \& Abdul, B.(2013). Technical vocational education (TVE) institutions and industries partnership: Necessity for graduates' skills acquisition. International Journal of Scientific and Research Publications, 3 (4), 1-4.

Salman, A. (2009). How to start a business: A guide for women. Pakistan: Center for International Private Enterprise, Institute of National Endowment for Democracy, affiliate of the USA Chamber of Commerce.

Samian, S. S. \& Buntat, Y.(2012). Self-employment: Perceptions among deaf students in Malaysian higher education through workplace experience. 3rd International Conference on Business and Economic Research (3rd ICBER 2012) Proceedings, pp.1545- 1556, held on 12-13 March 2012 at Golden Flower Hotel, Bandung, Indonesia.

Shane, S. (2003). A general theory of entrepreneurship: The individual-opportunity nexus. UK: Edward Elgar.

Shastri, R. K. \& Sinha, A. (2010). The socio-cultural and economic effect on the development of women entrepreneurs (with special reference to India). Asian Journal of Business Management , 2 (2), 30-34.

Stohmeyer, R. (2007). Gender gap and segregation in self-employment: On the role of field of study and apprenticeship training. Germany: German Council for Social and Economic Data (RatSWD).

Subramaniam, T. (2010). Micro enterprise and employment creation among the youths in Malaysia. Jati , 15, 151-166.

Tata, J. \& Prasad, S. (2008). Social capital, collaborative exchange and microenterprise performance: The role of gender. International Journal of Entrepreneurship and Small Business, 5 (3/4), 373-385.

Udida, L. A., Ukwayi, J. K. \& Ogodo, F. A. (2012). Parental socio-economic background as a determinant of student's academic performance in selected public secondary schools in Calabar Municipal L.G.A, Cross River State, Nigeria. Journal of Education and Practice (online), 3 (16), 129-134.

Universiti Malaysia Kelantan Convocation (2013). List of Graduands Konvokesyen Ke 3, 2013: 18, 73-86.

Weirich, H., Cannice, M. V. \& Koontz, H.(2008). Management: A global and entrepreneurial perspective(12 ${ }^{\text {th }}$ edition). New Delhi, McGraw-Hill Co. 